$$
\begin{aligned}
& \text { قسم طب انحيوان }
\end{aligned}
$$

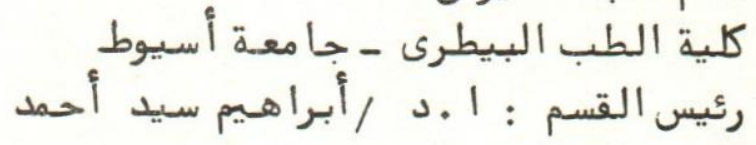

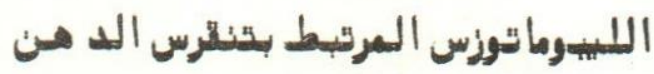

فى الابقار البلد ية

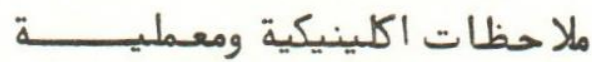

على السباعى ، نورالد ين حسان ، مهد اللطيف بيومى *، خيرى ابراهيم

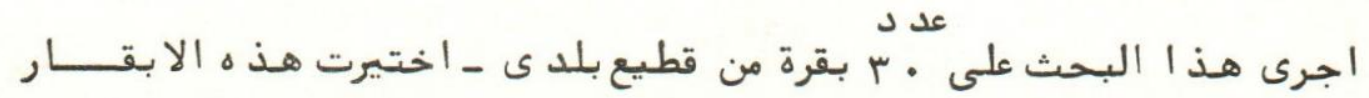

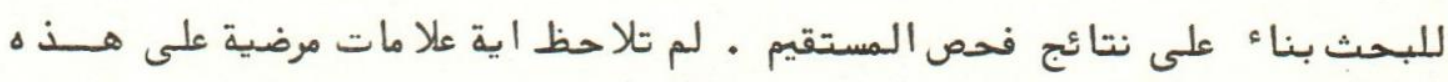

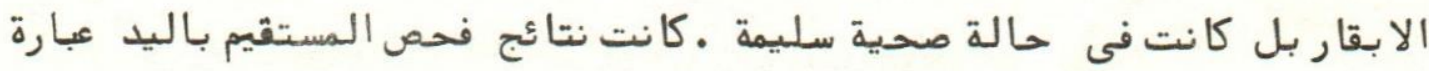

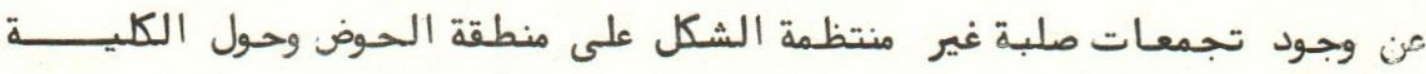

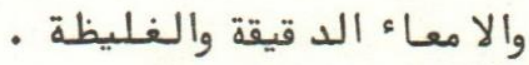

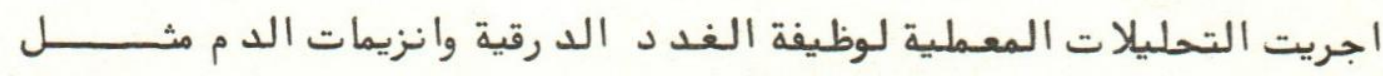

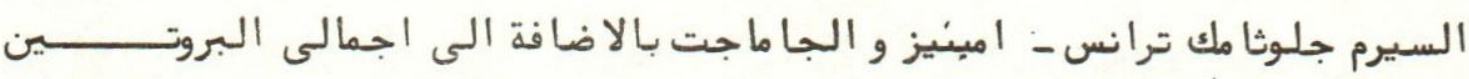

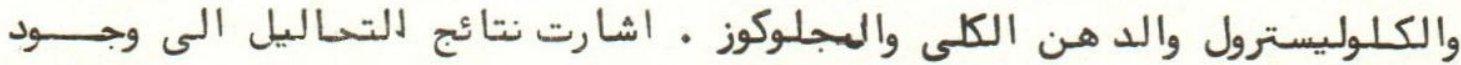
اخفاق ملحوظ فى وظيفة الغدة الد رقية .

* ق قسم الباثولوجسيا كلية الطب البيطرى - جامعة أسيوط 
Dept. of Animal Medicine, Faculty of Vet. Med., Assiut University, Head of Dept. Prof. Dr. I.S. Abdallah.

\title{
LIPOMATOSIS ASSOCIATED WITH FAT NECROSIS \\ IN NATIVE BREED COWS, EGYPT \\ 1- SOME CLINICAL AND BIOCHEMICAL OBSERVATIONS \\ (With Two Tables)
}

\author{
By \\ A. EL-SEBAIE; N.K. HASSAAN; A.H. BAYOUMI* \\ and M.KH. IBRAHIM * \\ (Received at 20/6/1984)
}

\begin{abstract}
SUMMARY
A total of 30 native breed cows were used in this investigation. Ten animals were clinically healthy, which served as a control, while the diseased cows were selected according to rectal findings. The animals were clinically and rectally examined. No obvious clinical symptoms were achieved, while hard irregular masses in the pelvic cavity were palpated. Biochemical analysis includes serum total proteins, cholesterol, total lipids, glucose, S-GOT, S-GPT, -GT, thyroid uptake and thyroxin were carried out in both healthy and diseased cows. Hypercholesterolaemia and hyperlipaemia were associated with hypothyroidism in diseased cattle.
\end{abstract}

\section{INTRODUCTION}

The occurrence of bovine lipomatosis has been given much attention by various workers. The condition was described as lipomatosis (Ito, Miura, OSHIMA and NUMAKUNAI, 1968). As a review on this disease, RUDDOCK (1936) identified such condition as lipomatous tumour which was found on area around the intestinal wall of a bull suffering from severe stenosis of the intestine.

Thereafter, many reports have been published on the disease; a review of these reports indicates that the identical lesions were present mainly in the adipose tissues of the abdominal cavity e.g. in the intestinal wall, mesentery, omentum, peritoneal adipose tissue (VITOVEC, PROKS and VALVODA, 1975).

In animals having these lesions chronic disturbance of digestion or colic symptoms have occasionally been observed clinically (ROSENBERGER, 1978), ITO et al. 1968. On the other hand the disease did not have any specific signs (PAPP and WILLIAMS, 1970).

Regarding the cause of such cases, there are different opinions in this respect. HOFLUND, HOLMBERG and NIKLEN (1953), attributed such condition to primary illness with peritonitis, long standing fever and enteritis generally in combination with circulating disturbances. DIRKSEN (1965) stated that hormonal disturbance could e a probable cause of such condition. Genetic influences were suggested after EDGSON (1952), ALBRIGHT (1960), and BRIDGE and SPARTLING (1962).

* Dept. of Pathology, Fac. of Vet. Med., Assiut University.

Assiut Vet.Med.J. Vol. 15, No. 29, 1985. 


\section{EL-SEBAIE, et al.}

In Egypt previous reports on such conditions were not yet published. Trials were conducted in this investigation to approach in detail some of the biochemical parameters, particularly the inter-relation-ship between fat metabolic pathway and the thyroid functional status.

\section{MATERIAL and METHODS}

A herd of 200 native breed cows was kept for milk production in dairy farm, Assiut, Egypt. Some cows died without apparent clinical signs. Autopsy findings revealed accumulation of fat masses, perineal fat, around the intestine and in the pelvic cavity. Twenty cows were selected according to the findings of rectal examination, while ten healthy cows were kept as a control without any obvious or rectal findings.

Blood samples were collected from these cows by means of vein puncture, later on serum was separated, collected and used for the biochemical assay and thyroid functional state. Total serum proteins, total lipids, cholesterol, glucose, S-GPT, SGOT and -GT were determined using reagent kits behringer Mannheim, W. Germany). Thyroid uptake and thyroxine were estimated using the enzyme immuno assay kit supplied by Immuno-tech. Corp. (Cambridge, MA, USA 02139). All these parameters were measured spectrophotometrically on an ultra violet/visible spectro-photometer (Beckman model 25).

\section{RESULTS}

\section{Clinical findings:}

In the present study, the examined cattle revealed no clinical signs that can be correlated with the internal changes. The general condition of the animals were healthy and in an excellent flesh. Rectal findings of the selected diseased cows revealed the presence of an irregular hard masses on the anterior floor and in the pelvic cavity. Theses hard masses interfered with the palpation of the caudal pole of the left kidney. In the severely affected cases it was so difficult to feel the intestine or even to palpate.

\section{Biochemical findings:}

Table (1) shows the values of parameters in healthy cows. The mean values were for serum proteins $(93.6 \pm 3.56 \mathrm{G} / \mathrm{L})$; cholesterol $(3.93 \pm 0.27 \mathrm{mmol} / 1)$; total lipids $(6.62 \pm 0.42 \mathrm{G} / \mathrm{L})$; glucose (2.99+ $0.39 \mathrm{mmol} / \mathrm{L})^{-} \mathrm{S}-\mathrm{GOT}(45 \pm 5.09 \mathrm{U} / \mathrm{L}) ; \mathrm{S}-\overline{\mathrm{GPT}}(16.7 \pm 3.02 \mathrm{U} / \mathrm{L})$ and $-\overline{G T}(9.89 \pm 1.39 \mathrm{U} / \mathrm{L})$. Mean values of thyroid functional status (table 1) of healthy cows were $1.02+0.05 \%$ and $9.38+0.639 \%$ for thyroid uptake and thyroxin respectively.

The values of measured parameters in the diseased cows were present in table (2). The mean values for serum total proteins, cholesterol, total lipids, glucose, SGOT, SGPT, and -GT, were $96.42 \pm 2.42 \mathrm{~g} / \mathrm{l}, 7.58 \pm 0.93 \mathrm{mmol} / \mathrm{L}, \quad 15.25 \pm 2.58 \mathrm{~g} / \mathrm{l}, 2.48 \pm 0.96 \mathrm{mmol} / \mathrm{L}, 57 \pm 13.5 \mathrm{U} / \mathrm{L}, 25+4.7$ $\mathrm{U} / \mathrm{L}$ respectively, while the mean values for thyroid uptake and thyroxine were $0.80 \pm 0.12 \%$ and less than $4.7 * 9 \%$ respectively.

\section{DISCUSSION}

Twenty cases in the present investigation of bovine lipomatosis were investigated clinically and pathologically, they revealed no clinical signs, however, they showed an excellent healthy

* The used enzyme immune assay method is sensetive at concentration of thyroxin not less than 4.7 ug\%.

Assiut Vet.Med.J. Vol. 15, No. 29, 1985. 
appearance, that agree best with those observations mentioned by PAPP and WILLIAMS (1970). On the contrary, these findings disagree with the clinical signs recorded by ITO et al. (1968).

The condition was recorded recently in the south of Assiut Upper Egypt as an enzootic herd problem.

Hypercholesterolaemia (mean value $7.58+0.93 \mathrm{mmol} / \mathrm{L}$ ) was recorded in the diseased cows, if compared with the cholesterol values in healthy cows (mean value $3.93+0.27 \mathrm{mmol} / \mathrm{L}$ ), this also associated with a marked increase of total lipids (mean value $15.25+2 . \overline{5} \mathrm{G} / \mathrm{L}$ ). A distinct decrease in both thyroid uptake (mean value $0.80+12 \%$ ) and thyroxin level (less than** $4.7 \mathrm{~g} \%$ ) was observed accompanying hypercholesterolaemis and hyperlipaemia, this throw some light upon the interrelationship between fat metabolism and the thyroid dysfunction, that may suggest thyroid involvement. Of great interest to state here that the aformentioned results are in full agreement with those of KANEKO (1970) that the level of cholesterol is affected by thyroid activity and that varies inversely with the degree of the activity. Values of cholesterol and total lipids in the most severely affected cases (cows No. 5, 7, 9 and 10) run synchronized with the findings of thyroid function (table 2) and findings of rectal examination as well. The macro-and micromorphological studies recorded by BAYOUMI; IBRAHIM; HASSAAN and EI-SEBAIE (1984) would confirm our clinical and biochemical findings. This could help the clinician to depend partially upon these parameters as a laboratory aid for early diagnosis of bovine lipomatosis. Final diagnosis of such cases based not only on biochemical findings but also on the identification of the disease macroand micoscopically. In the available literature no definite evaluation of thyroid function status in relation to bovine lipomatosis was discussed.

Serum enzyme activities in diseased animals gave an indication that the liver, to a certain extent, got involved in the pathogenesis of such cases. A marked elevation of serum -GT activity (mean value $22.53+4.50 \mathrm{U} / \mathrm{L}$ ) was observed, this enzyme is considered a specific diagnostic enzyme for liver dysfunction in bovine. Also the activities of SGOT and SGPT were to less extent increased, which were $57 \pm 13 \mathrm{U} / \mathrm{L}$ and $25+4.7 \mathrm{U} / \mathrm{L}$ respectively.

Regarding the serum total proteins as well as serum glucose levels, no markable changes were observed in such cases, if compared the mean values of diseased and healthy cows (table 1 \& 2).

\section{REFERENCES}

Albright, J.L. (1960): Multiple lipomatosis in dairy cattle. J. Hered. 51: 231.

Bayoumi, A.H.; M.K. Ibrahim; N.K. Hassaan and A. El-Sebaie (1982): Lipomatosis associated with fat necrosis in native breed cows, Egypt. II- Macro-and Micromorophological studies (in press). 1st Assiut Vet. Sci. Congress (1984).

Bridge, P.S. and Spartling, P.R. (1962): Bovine lipomosis. Vet. Rec. 74: 135 (1961).

Dirksen, G. (1965): Klinische Beobachtungen uber die fettgewebsnekrose beim Rind. Wien. Tierarztl. Mschr., 52, 517-525.

Edgson, F.A. (1952): Bovine lipomotosis. Vet. Rec. 104: 449.

Hoflund, S.; Holmberg, K.B. and H. Niklen (1953): On the aetiology, pathogenesis and clinical picture of fat Necrosis in cattle. Proc. 15th Internat. Vet. Cong. Stockholm. 1, 642-652.

- The used enzyme immune assay method is sensetive at concentration of thyroxin not less than 4.7 ug\%.

Assiut Vet.Med.J. Vol. 15, No. 29, 1985. 
Ito, Takao, Sadao Miura; Kan-ichi, Ohshimi and Sigeru, Numakunai (1968): Pathological studies on fat necrosis (Lipomatosis) in cattle. Jap. J. Vet. Sci. 30, 141-150.

Kaneko, J.J. (1970): Thyroid function. In: Clinical Biochemistry of Domestic Animals, edited by Kaneko, J.J. and Cornelius, C.E., Vol. 1, 2nd ed., Academic Press, N.J.

Papp, E. and J. Williams (1970): Bovine lipomotosis. Z. Veterinar. Med. A., 17, 735-742.

Rosenberger J. (1978): Krankheiten des Rindes. Verlag. Paul. Parey. 2 Auflage.

Ruddock, H.B. (1936): Vet. J., I. Cited after ITO, Takao, Sadao Miura, Kan-ichi Ohshima and Shigeru Numakunai (1962). Pathological studies on the Necrosis (Lipomotosis) in cattle. Jap. J. Vet. Sci., 90, 141-150 (1968).

Vitovec, J.; C. Proks and V. Valvoda (1975): Lipomotosis (Fat Necrosis) in cattle and pigs. J. Comp. Path. 85: 53-58.

Table 1: Values of total proteins, cholesterol, total lipids, glucose, S-GOT, SGPT, $\boldsymbol{\gamma}$-GT, Thyroid uptake, and thyroxine in clinically healthy cows.

\begin{tabular}{|c|c|c|c|c|c|c|c|c|c|}
\hline $\begin{array}{l}\text { Case } \\
\text { No }\end{array}$ & $\begin{array}{l}\text { Total } \\
\text { proteins } \\
\text { G/L }\end{array}$ & $\begin{array}{l}\text { Cholesterol } \\
\text { mol/h }\end{array}$ & $\begin{array}{l}\text { Iotal } \\
\text { lipid } \\
\mathrm{G} / \mathrm{L}\end{array}$ & $\begin{array}{l}\text { Glucose } \\
\mathrm{mmol} / \mathrm{L}\end{array}$ & $\begin{array}{l}S-G O T \\
U / L\end{array}$ & $\begin{array}{l}\text { S-GPT } \\
U / L\end{array}$ & $\begin{array}{l}X=G T \\
U / L\end{array}$ & $\begin{array}{l}\text { Thyroid } \\
\text { uptake } \\
\%\end{array}$ & $\begin{array}{c}\text { Thyroxine } \\
\text { ug\% }\end{array}$ \\
\hline 1 & 90 & 3.7 & 6.8 & 2.01 & 40 & 10 & 8.45 & 1.05 & 8.63 \\
\hline 2 & 95 & 4.0 & 7.0 & 2.90 & so & 15 & 10.40 & 0.97 & 9.14 \\
\hline 3 & 89 & 4.2 & 6.5 & 3.21 & 35 & 18 & 8.30 & 1.05 & 9.38 \\
\hline 4 & 92 & 4.1 & 7.3 & 2.85 & 48 & 20 & 9.90 & 0.98 & 10.40 \\
\hline 5 & 97 & 4.3 & 6.2 & 3.45 & 50 & 20 & 12.14 & 0.98 & 9.37 \\
\hline 6 & 90 & 4.2 & 6.1 & 3.35 & 45 & 18 & 11.30 & 1.06 & 9.48 \\
\hline 7 & 92 & 3.9 & 6.5 & 2.97 & 45 & 15 & 10.30 & 1.06 & 8.40 \\
\hline 8 & 94 & 3.5 & 6.6 & 2.83 & 40 & 18. & 11.11 & 0.99 & 10.31 \\
\hline 9 & 99 & 3.8 & 7.1 & 3.40 & 48 & 15 & 8.40 & 1.08 & 9.48 \\
\hline 10 & 98 & 3.6 & 6.8 & 2.90 & 49 & 18 & 8.60 & 1.08 & 9.60 \\
\hline * & 93.6 & 3.93 & 6.62 & 2.99 & 45 & 16.7 & 9.89 & 1.023 & 9.38 \\
\hline S.D. & \pm 3.56 & \pm 0.27 & \pm 0.42 & \pm 0.39 & \pm 5.09 & \pm 3.02 & \pm 1.39 & \pm 0.05 & \pm 0.63 \\
\hline
\end{tabular}

* $=$ Mean

S.D. =Standard deviation $n=10$ 


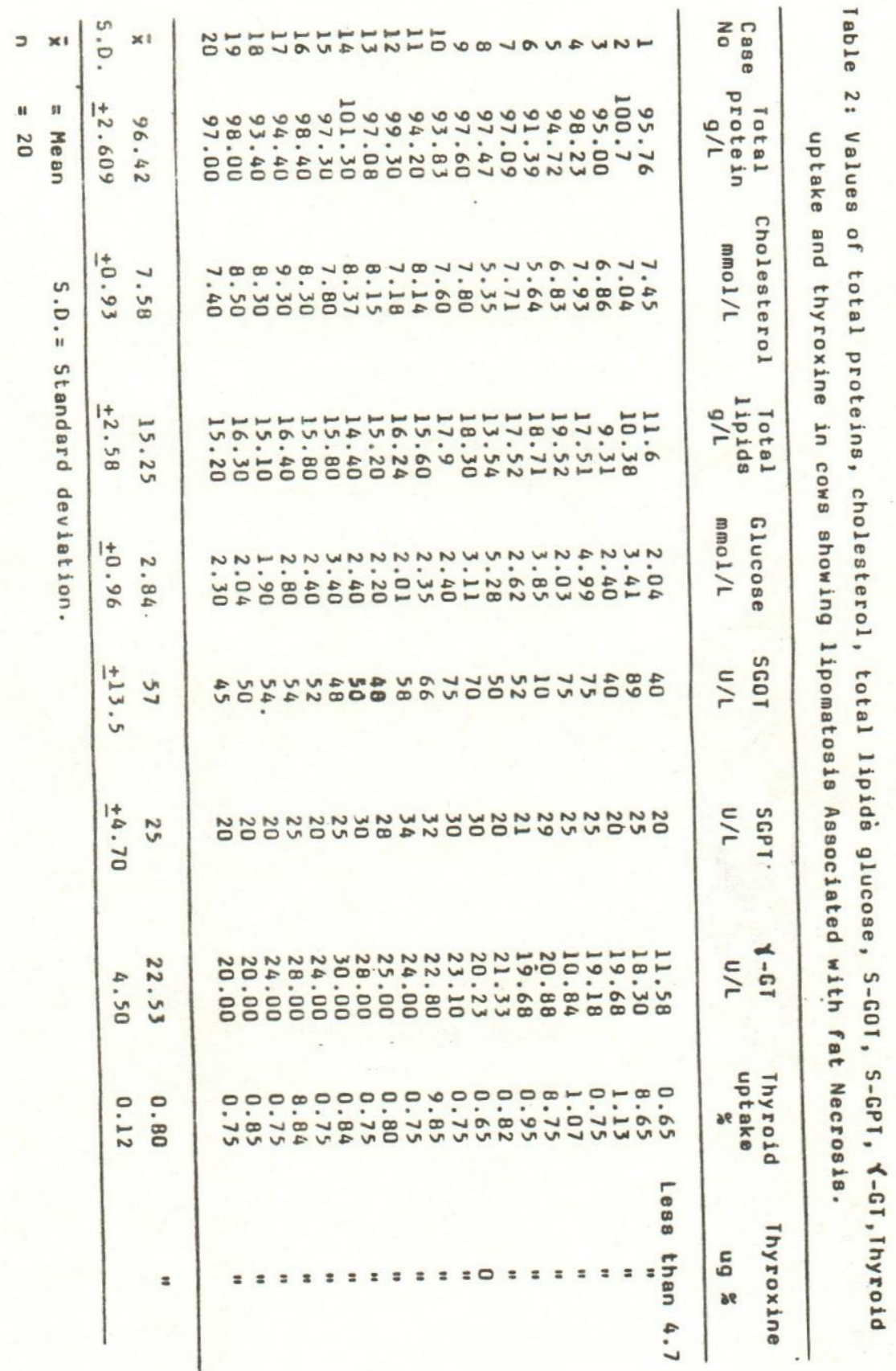




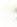

